\title{
Ser Humano na Era da Reprodutibilidade Técnica
}

Marcos Nalli José Fernandes Weber Professores da Universidade Estadual de Londrina

\section{Resumo}

Nosso propósito é buscar apresentar algumas possibilidades de reflexão que permitam articular o homem, sua natureza, e o advento das novas tecnologias. Ora, as novas tecnologias - a biotecnologia, a genética, a nanotecnologia e as ciências informacionais - parecem convergir no sentido de forçar a se repensar a própria natureza humana tomando-a também como uma espécie de artefato. Procuraremos estabelecer, por fim, algumas pistas reflexivas sobre os objetos e artefatos tecnológicos, principalmente em função de sua natureza protética, como mediadores políticos e éticos.

Palavras-chave: Ser Humano; Reprodutibilidade Técnica; Novas Tecnologias.

\begin{abstract}
Our purpose is to seek to present some possibilities of reflection that bring the man, his nature, and the advent of new technologies. However, new technologies - biotechnology, genetics, nanotechnology and informational sciences - seem to converge in order to force a rethink human nature taking it as a sort of artifact. We seek to establish, finally, some reflections on the objects and technological artifacts, mainly due to its nature prosthetics, political and ethical as mediators.
\end{abstract}

Keywords: Human Being; Technical Reproducibility; New Technologies. 
ma advertência prévia. $\mathrm{O}$ título ${ }^{1}$ é uma provocação. Talvez nem mais e nem menos que uma provocação. Parcialmente, sua ideia veio do título do famoso artigo do filósofo alemão Walter Benjamin, A obra de arte na era de sua reprodutibilidade técnica, escrito entre 1935 e 1936, em pleno auge do fascismo e do nazismo na Alemanha. Nesse texto célebre, Benjamin observa que, embora a obra de arte sempre foi reprodutível, algo novo começa a se dar com a reprodutibilidade técnica: primeiramente liberando a mão do processo reprodutivo imagético, o que o tornou mais rápido, apenas afeito a apreensão do olhar; e desde o século XIX, a reprodução sonora alcançou um padrão de qualidade e incorporou como seus objetos toda a obra de arte musical. Ainda assim, há um traço típico da obra de arte, que faz dela autêntica, que escapa da mais perfeita reprodução, isto é, o "aqui e agora do original", a "esfera da autenticidade" da obra de arte (Benjamin, 1985, p. 167). Há, neste sentido a perda gradativa do que ele designou por "aura".

Generalizando, podemos dizer que a técnica da reprodução destaca do domínio da tradição o objeto reproduzido. $\mathrm{Na}$ medida em que ela multiplica a reprodução, substitui a existência única da obra por uma existência serial. E, na medida em que essa técnica permite à reprodução vir ao encontro do espectador, em todas as situações, ela atualiza o objeto reproduzido. Esses dois processos resultam num

\footnotetext{
${ }^{1}$ Texto resultante das seguintes atividades de pesquisa: 1. Pós-Doutorado (Novembro/2013 a Outubro/2014) no Programa de Pós-Graduação em Educação da Universidade Paulista Júlio de Mesquita Filho (UNESP), campus de Marília, sob supervisão do Prof. Dr. Pedro Angelo Pagni, com Bolsa financiada pelo Programa CAPES/PNPD; 2. Projeto de Pesquisa "Técnica, tecnologia em Heidegger e Simondon: destruição do pensamento ou ampliação da experiência?" - PROPPG/UEL, financiado pelos seguintes órgãos de fomento: 1. MCTI/CNPq/CAPES (Chamada 07/2011); 2. Edital MCTI/CAPES/CNPQ 14/2012 Universal; 3. Fundação Araucária (Chamada 05/2011); 4. FAEPE/UEL (Edital 01/2011); 5. Fundação Araucária (Bolsa Produtividade Em Pesquisa/2013) e Proejto de pesquisa "A imanência normativa da vida e da morte nas análises da biopolítica" - Apoiado pelo $\mathrm{CNPq}$ (Processo 304958/2013-1).
}

Filosofia e Educação - ISSN 1984-9605

Volume 6, Número 3 - Outubro de 2014 
violento abalo da tradição, que constitui o reverso da crise atual e a renovação da humanidade (Benjamin, 1985, p. 169).

Este abalo da tradição se faz notar, por exemplo, com o advento da fotografia, na qual a foto como objeto se caracteriza por exigência de reprodução. A foto é o primeiro objeto de arte que quebra a estreita relação existente entre a arte e a teologia ritualística que era subjacente a toda obra de arte até então. Pela reprodutibilidade técnica, o objeto de arte se dá o tempo todo, e sua existência depende de modo inexorável de que seja continuamente reproduzido - "A obra de arte reproduzida é cada vez mais a reprodução de uma obra de arte criada para ser reproduzida" (Benjamin, 1985 , p. 171); e a isto Benjamin interpretou como uma forma de emancipação, justamente por que, ao se liberar de uma teologia do ritual, que lhe conferia uma espécie de aura, sua autenticidade agora tem que ser transformada de modo a ser oriunda da práxis política; o que faz da obra de arte, uma criação da coletividade, sujeita à exposição e difusão. Aliás, na era de sua reprodutibilidade técnica, a obra de arte, por se oriunda, ou por se assentar fundamentalmente em sua reprodutibilidade técnica, tem que ser necessariamente objeto de reprodução e, pois, de exposição e difusão massiva. Está aí, por assim dizer, a sua "razão de ser".

E o que o título tem a ver com a questão, deveras importante, proposta por Benjamin? Ainda temos que pensar o que mais há de provocativo no título... Começamos por sua parte final, sobre a noção de reprodutibilidade técnica, como se a expressão "ser humano" fosse óbvia e escapasse a toda sorte de questões. Será mesmo? Primeiramente, tomamos a expressão como um nome, como um substantivo, como um signo com o qual designamos algo. Se seguirmos a lógica usual para casos assim, diríamos que a exatidão semântica de tal signo advém da objetividade e 
permanência "natural" e inexorável desse ente que é designado por tal expressão, isto é, esse ente - que facilmente identificamos a nós mesmos - e que o nomeamos "ser humano". Mas se diz "ser humano" é justamente para não dizer tão rapidamente "humano" ou "homem": mais do que enfatizar o substantivo masculino "humano", que também pode ser utilizado para generalizar e caracterizar todo um coletivo, incluindo aí os gêneros masculino e feminino, e até os trans-gêneros, o que queremos é enfatizar o verbo "ser", intransitivo, mas também auxiliar. No infinitivo, o verbo deixa de sê-lo e passa a ser nome, isto é substantivo. De qualquer modo, ao substantivá-lo, o que se faz é neutralizar a sua temporalidade; mas não eliminamos - assim me parece - sua natureza semântica peculiar neste caso, isto é, sua propriedade aspectual: ao dizer "ser humano", pode-se compreender na expressão um sentido processual, que se dá no tempo e na história, que parece implicar uma lógica teleológica cujo fim é dado, ou processualmente visado, na expressão, indicado pelo vocábulo "humano". Assim, a unidade sintagmática "ser humano" não indica um fato natural, um dado pronto e acabado, mas um processo com fim bem demarcado. Ser humano, portanto, é usado aqui não para designar o humano propriamente dito, mas aquele ente que é cada um de nós, que somos todos nós, que agimos de múltiplos modos para nos fazermos efetivamente humanos. Se quisermos ainda brincar um pouco mais com a ideia, não somos humanos em ato; mas tão somente em potência. E mais, em possibilidade: podemos nos tornar humanos; podemos fazer de nós mesmos seres humanos. Não se trata, agora com este outro verbo, "poder", conjugado no presente do indicativo, de indicar nossa força, nossa capacidade; também isso, mas de que esta força nos lança para um fim que não é o da certeza e da inevitabilidade, mas para o intricado caminho da possibilidade, poderíamos até dizer, da sorte, da chance e da probabilidade: a possibilidade de que 
temos, de que podermos nos tornar humanos é tão forte, tão grande, que não apenas é possível como é até provável que isto ocorra... Que nos tornemos humanos. Isto quer dizer então que não o somos? Talvez... Senão, vejamos.

Durante eras, séculos, gerações inteiras, esforçamo-nos em criar taxonomias, classificações, hierarquias, diferenciações dos mais variados tipos e espécies. Estavam implicadas nesses esforços muitas coisas, dentre elas o esforço de ver e de ler toda a realidade, e toda a natureza por meio de classificações e diferenciações entre gêneros e espécies, geralmente por estruturas binárias. É assim que dividimos o real em céu e terra; em terra e mar; em luz e trevas; em orgânico e inorgânico; em animal, vegetal e mineral; em simples e complexo; em natural e artificial; em normal e anormal; em saúde e doença; em natural e artificial.

A relação do homem, do animal humano com os artifícios sempre foi uma constante histórica. Já na Teogonia (590-593) de Hesíodo encontramos a referência ao mito de Prometeu. Tendo os deuses olímpicos incumbido o titã Epimeteu, irmão de Prometeu, a incumbência de criar os animais e a Prometeu a tarefa de supervisionar a criação dos seres vivos, aquele se pôs à tarefa criadora de modo a distribuir velocidade, astúcia, fortaleza, dissimulação a todos os animais criados, de modo que ao criar os primeiros homens não lhe restava mais outra matéria-prima senão o barro. O sentido o mais evidente dessa história é que o homem é dentre os animais, o mais fraco, o mais desprovido de recursos que lhe possam garantir subsistência e sobrevivência diante dos desafios e das ameaças da natureza. Vendo tamanha limitação, parece que Prometeu se comove com a fragilidade humana e astutamente rouba de Zeus o fogo para em seguida dar-lhe aos homens - o que teve conseqüências muito sérias ao infrator, sendo brutalmente punido. Que ideia emerge daqui? O que o presente, o fogo, representava aos frágeis e indefesos humanos?

Filosofia e Educação - ISSN 1984-9605

Volume 6, Número 3 - Outubro de 2014 
Como toda a antropologia biológica sabe categoricamente, o animal humano, dentre todos os animais, é um dos mais frágeis ao nascer. Suas medidas são desproporcionais, ele nasce desprovido de pelos que possam lhe proteger do frio, ele leva muito tempo para aprender a engatinhar e a andar, o que por si já é um risco para si mesmo e para sua mãe que tem que carregá-lo, acalentá-lo, aquecê-lo, alimentá-lo, e que se torna, dia após dia num pesado fardo para sua genitora, não consegue se comunicar, apenas chora e seus genitores levam muito tempo até aprenderem a interpretar - e ainda assim com grande possibilidade de erro e de stress oriundo desse erro - seus choros e berros; nos primeiros meses passa a maior parte do tempo, inclusive, dormindo. Não sabe se alimentar, não sabe onde se livrar de seus dejetos. Os genitores precisam estar o tempo todo atentos a tudo o que ocorre com o indefeso e prematuro animal, para garantir minimamente sua preservação e, de um ponto de vista evolutivo, também da possibilidade de perpetuação de sua espécie. Ainda que segundo alguns antropólogos e biólogos, o que caracteriza o humano seja seu telencéfalo desenvolvido e seu polegar opositor, leva muito tempo após o seu nascimento até que o telencéfalo se desenvolva e que o filhote de humano consiga usar a contento seus polegares opositores para fazer jus às funções que se esperam deles, e para as quais eles foram moldados. Portanto, praticamente desde que o filhote humano nasce, seus genitores recorrem a expedientes artificiais, como a roupa e a manta, para proteger sua cria.

Tais expedientes artificiais podem ser entendidos perfeitamente como próteses. Mas as próteses são de vários tipos, não apenas em relação a sua funcionalidade, mas também em relação ao sentido que assume nas vidas humanas. A roupa e a manta que os genitores humanos se valem para aquecer e proteger seu filhote, e certamente a si mesmos, são como que uma segunda pele. Mas também é um código, uma mensagem, cifrada em alguns 
aspectos e explicita em outros. Pode-se pela segunda pele, isto é, a roupa, demarcar diferenciações socioeconômicas, ou mesmo culturais e religiosas. Os calçados que se usa são como que cascos que permitem ao ser humano pisar e transitar nos mais diferentes pisos, mas também podem ser evidente instrumento de aprimoramento e refinamento da silhueta, realçando seus traços eróticos e mesmo conclamando e incitando às relações eróticas. Os óculos são como que olhos melhorados e que conferem ao seu usuário uma visão, às vezes mais refinadas e acuradas que a de outros indivíduos não usuários. O que dizer então do binóculo, do telescópio e do microscópio, do carro e do avião. As próteses são assim como que extensões do corpo humano, ou extensões de funções do corpo humano. A faca, por exemplo, que é com seu cabo, uma extensão do braço e da mão, enquanto sua lâmina é um refinamento e aguçamento dos dentes. Neste sentido, os artefatos tomados como próteses cujo fim explícito é possibilitar ou aprimorar alguma ação, algum comportamento, ou algum feito humano, apontam para a incompletude do ser humano; mas como também se deve notar, segundo o historiador da arquitetura Adrian Forty (2006, p. 29s),

A mais valiosa aplicação da protésica é, de longe, na estética do design, onde ela oferece algumas percepções úteis. Se considerarmos os objetos como extensões do corpo, resulta então que eles podem dar em troca prazer ao corpo - como membros e órgãos suplementares eles oferecem prazeres auto-eróticos que complementam os prazeres que nos dão os nossos órgãos naturais. Os artigos que pertencem à categoria geral da estética são, por definição, coisas cuja proximidade com o nosso corpo permitimos: eles tocam a nossa pele, passamos os dedos por eles, aproximamo-los dos nossos lábios. [...] os artigos da alta-costura podem aumentar a sensação do nosso próprio corpo, oferecendo sensações novas e variadas e jogando com os contrastes

Filosofia e Educação - ISSN 1984-9605

Volume 6, Número 3 - Outubro de 2014 
entre apertado e solto, entre peso e leveza, entre coberto e descoberto, entre aspereza e maciez e entre contrastes de texturas [...] Da mesma forma, usar uma chave de parafusos não é apenas um trabalho, também estimula a consciência da sensação do tacto, nem o ato de beber de um copo é apenas a satisfação da sede, mas também nos dá experiências sensoriais nos lábios, na mão e nos olhos. O cabo da chave de parafusos com um melhor acabamento transmite uma sensação diferente da de um cabo com um acabamento mais grosseiro. O copo de Vidor mais fino e mais transparente transmite ao ato de beber uma sensualidade que não se encontra se bebermos por um copo mais grosseiro ou por uma xícara de plástico.

Para além do aspecto protético, os avanços tecnológicos que assistimos desde meados do século XIX apontam-nos para uma outra dimensão, certamente já prenunciada na tese da prótese como extensão do corpo e de sua funcionalidade. Se a incompletude do animal humano parece só ser superada mediante os aprimoramentos cinéticos obtidos com as próteses, a própria integridade humana (no sentido de sua completude visada e não no sentido de uma dignidade ou sacralidade da pessoa humana) só parece ser alcançada a partir do mais íntimo entrelaçamento entre natureza e artificialidade. O que caracteriza em termos biológicos um organismo, um ser vivo? De certo modo, todo organismo, desde os mais simples e unicelulares, até os mais complexos - que em geral, e presunçosamente, acreditamos ser nós mesmos - desenvolvemos basicamente três funções, que obviamente podem variar ou se diferenciar ganhando outras tantas nuances e funções, mas comumente entrelaçadas com essas três funções: buscar alimentos, fugir de toda e qualquer ameaça, e procurar perpetuar a espécie, seja pela divisão celular, seja pela cópula sexual. O animal humano, para conseguir atender tais funções-demandas, 
provavelmente devido à sua fragilidade bio-evolutiva, tratou de se valer de todos os meios artificiais que logo dispôs. E logo, pelo menos em termos da temporalidade evolutiva dos organismos, o animal humano desenvolveu aprimoramentos cada vez mais radicais aos seus primeiros utensíliospróteses. Em pouco tempo alterou de modo tão significativo seu bioma natural que criou outro só para si, a cidade e a vida urbana. Alterou seus códigos e criou códigos artificiais mais elaborados cujo fim seria justamente o de regrar sua vida no seio urbano. Formulou o Direito, e nele, criou estratégias jurídicas curiosas, como por exemplo o conceito de pessoa, ou do início da vida. $\mathrm{O}$ animal humano criou para si algo mais complexo, mais etéreo, menos material, mais difuso e extremamente poderoso: a Cultura, que tem a capacidade, inclusive, de domesticar o animal humano. Aqui, faço minhas as poderosas e polêmicas ideias já enunciadas pelo filósofo alemão Peter Sloterdijk.

Entre setembro e novembro de 1999, na Alemanha, ocorreu um acirrado debate motivado pelo ensaio publicado pelo filósofo Peter Sloterdijk, Regras para o Parque Humano: uma resposta à carta de Heidegger sobre o humanismo. Como bem observa o filósofo alemão, este debate provocado pela des-contextualização e pela desconstrução jornalística e midiática, culminando numa situação escandalosa (o "escândalo Sloterdijk-Habermas", como se referiam os franceses à polêmica), foi um dos efeitos deletérios decorrentes do ensaio de Sloterdijk, originalmente uma palestra em Basiléia e Elmau, entre os anos de 1997 e 1999. Ainda segundo Sloterdijk, esse efeito se dá a partir de um dos trechos finais do ensaio no qual apontou para

Alguns problemas que podem ser levados quanto aos desdobramentos futuros da espécie decorrentes da emergência das novas possibilidades

Filosofia e Educação - ISSN 1984-9605

Volume 6, Número 3 - Outubro de 2014 
de intervenção biotécnica. Levantei ali a questão de se, a longo prazo, algo como um planejamento explícito de características no plano da espécie seria de algum modo possível, e se o nascimento opcional (com sua contrapartida, a seleção pré-natal) poderia se tornar uma nova prática em assuntos de reprodução, no âmbito de toda a espécie [...] e na mesma passagem acrescentei que é sob a forma de questões temerárias como essa que se descortina à nossa frente o horizonte evolucionário. Essas questões foram transformadas por alguns jornalistas em prescrições (Sloterdijk, 2000, p. 62).

Sem ater aos motivadores da polêmica, é preciso considerar uma outra idéia enunciada por Sloterdijk, porém pouco tematizada:

Certamente, a leitura (Lesen) teve um imenso poder na formação humana - e, em dimensões mais modestas, continua a tê-lo; a seleção (Auslesen), contudo - seja como for que tenha sido levada a cabo sempre funcionou como a eminência parda por trás do poder. Lições e seleções têm mais a ver entre si do que qualquer historiador da cultura quis ou pôde levar em conta e, ainda que nos pareça impossível por ora reconstruir de forma suficientemente precisa a conexão entre leitura e seleção, considerar que essa conexão, enquanto tal, possui algo de real, é mais que uma simples hipótese descompromissada (Sloterdijk, 2000, pp. 43-44).

Ou seja: a distância entre educação - no sentido atribuído pelos humanistas, isto é, de educação pela formação humana - e tecnologia, especialmente as tecnologias que afetam direta ou indiretamente a natureza e condição humana, como as biotecnologias, não é tão grande como se pode supor a princípio. E essa distância, ou melhor, sua proximidade, fica bem menor se levarmos em conta seus aspectos políticos.

Filosofia e Educação - ISSN 1984-9605

Volume 6, Número 3 - Outubro de 2014 
A afirmação de Sloterdijk é polêmica e escandalosa: à tese já clássica (e de certo modo agastada) da oposição "educação ou barbárie", ele a embaralha propondo uma outra relação: educação e técnica. Não como uma nova oposição, mas sugerindo à educação, à sua definição, outros elementos que lhe são constitutivos, notadamente sua natureza técnica. A oposição "educação ou barbárie”, ou se preferirmos "educação ou bestialidade" se ampara na tese de que pela educação, nos humanizamos e somos retirados de um estágio ou condição de embrutecimento e barbárie:

O humanismo, como palavra e como assunto, sempre tem um 'contra quê', uma vez que constitui o empenho para retirar o ser humano da barbárie. [...] Quem hoje se questiona sobre o futuro da humanidade e dos meios de humanização deseja essencialmente saber se subsiste alguma esperança de dominar as atuais tendências embrutecedoras entre os homens. Quanto a isto, tem uma perturbadora importância o fato de que o embrutecimento, hoje e sempre, costuma ocorrer exatamente quando há grande desenvolvimento do poder, seja como rudeza imediatamente bélica e imperial, seja como bestialização cotidiana das pessoas pelos entretenimentos desinibidores da mídia. [...] O tema latente do humanismo é, portanto, o desembrutecimento do ser humano, e sua tese latente é: as boas leituras conduzem à domesticação (Sloterdijk, 2000, pp. 16-17).

Não precisamos projetar um futuro, tenebroso ou glorioso, para vermos a coerência da leitura do filósofo alemão. A nossa história recente já nos dá várias provas dessa relação que assustou tantos jornalistas e alemães, provavelmente ainda muito afetados e marcados por sua história recente, notadamente às voltas com a ascensão de Hitler e os desdobramentos da Segunda Guerra. Mas será que com tais desdobramentos, instalou-se uma cesura entre educação e técnica? O texto de Sloterdijk parece sugerir-nos

Filosofia e Educação - ISSN 1984-9605

Volume 6, Número 3 - Outubro de 2014 
que não. A domesticação humana como o traço latente da formação educativa ainda mantém suas amarras com a questão das novas tecnologias que nos convidam a projetar um novo futuro ao homem; um futuro onde os recursos às avançadas tecnologias não nos contrapõem à natureza, mas colocam-nos todos, homem e natureza, numa relação imbricada de adulteração e manipulação de nossas condições elementares.

Os arautos das novas tecnologias não mais se perguntam como alterar a natureza, como afetá-la e como constrangê-la às nossas vontades. Não se trata mais de se inquirir como ter a natureza à mão, mas de como imitá-la, de como emulá-la. O grande desafio das novas tecnologias, até para superar os seus limites, é de como desenvolver estratégias tecnológicas que emulam a natureza. Na informática, o desafio consiste em fazer com que as informações, baseadas em bits, possam ser processadas e repassadas entre as partes componentes de um sistema a partir dos elétrons (computação quântica). Não está mais em jogo a corrida pelo mapeamento genético; a questão agora reside em como reescrever as informações genéticas a partir das mais variadas cartografias, manipulando as ordens de cada unidade molecular numa sequência de DNA (genômica). Em pouco tempo, poderemos dispor de nanocomputadores de DNA ou RNA, cuja função será rastrear e monitorar nossos corpos de tal modo a auxiliar e garantir-nos uma condição saudável, isto sem considerar as possibilidades de novos implantes biomecânicos (são algumas das propostas audaciosas da nanomedicina e da bioengenharia e biotecnologia). A emulação da natureza deverá ter como um de seus impactos mais significativos a alteração de nossa natureza constitutiva. As novas tecnologias, assim, concorrem em direção a uma nova formação do homem, uma nova Bildung, que nos constituirá, não mais no sentido preconizado pelo humanismo clássico, iluminista em sua crença cega no poder da razão (universalizada porque singular), mas numa nova 
cultura, uma cultura eminentemente tecnológica, da qual a educação poderá fazer parte. Aliás, se os exercícios variados do processo educacional assumirem sua condição formativa, em particular, sua condição selecionadora, ela inevitavelmente será parte constitutiva desse projeto de fazer ser, de constituição do humano.

Agora, outro aspecto se faz aqui pertinente e que não pode ser desconsiderado. Se a educação tem um caráter seletivo, uma das formas que ela pode assumir como formação, então a questão que se coloca é: o que a educação seleciona? E enquanto seletiva, como se relaciona com as tecnologias em geral? Não há como negligenciar, principalmente se considerarmos a contraposição mais evidente - e que tentamos de modo sumário apresentar aqui, porém numa tônica menos alarmante - com a eugenia, que se trata de um movimento seletivo bastante peculiar, no qual se almeja intensificar e afetar o próprio processo de seleção natural, outrora preconizado pelo naturalista Charles Darwin e exposto por ele em sua $A$ Origem das Espécies (1859). E esta seleção se deveria aplicar de modo intensivo não sobre os seres vivos em geral, mas em um animal de modo bastante particular: o homem. A zootecnia se especializaria aqui numa antropotecnia. As tecnologias seriam, assim como a educação, uma especiação da cultura, enquanto forma de cultivo e modo de produção. Foucault, em Vigiar e Punir (Surveiller et Punir), já identificava esse fenômeno, entendido por ele como uma das consequências da matriz disciplinar que afeta toda a tessitura social (Foucault, 1987: 261) e condiciona e produz as multiplicidades: o preso, o doente, o louco, o idoso, o soldado, o educando. A educação e a escola, como um dos vetores possíveis das relações de poder que permeiam as sociedades contemporâneas, seleciona e produz nossa alma, nossa "realidadereferência" reclamada como nossa condição indelével e primeira por todos 
os humanismos. Nossa alma, nossa subjetividade, não é uma condição, uma causa antecedente ou um fim às relações sociais e políticas; é um efeito de poder.

Esta alma real e incorpórea não é absolutamente substância; é o elemento onde se articulam os efeitos de certo tipo de poder e a referência de um saber, a engrenagem pela qual as relações de poder dão lugar a um saber possível, e o saber reconduz e reforça os efeitos de poder. Sobre essa realidade-referência, vários conceitos foram construídos e campos de análise foram demarcados: psique, subjetividade, personalidade, consciência, etc.; sobre ela técnicas e discursos científicos foram edificados; a partir dela, valorizaram-se as reivindicações morais do humanismo. Mas não devemos nos enganar: a alma, ilusão dos teólogos, não foi substituída por um homem real, objeto de saber, de reflexão filosófica ou de intervenção técnica. O homem de que nos falam e que nos convidam a liberar já é em si mesmo o efeito de uma sujeição bem mais profunda que ele. Uma 'alma' o habita e o leva à existência, que é ela mesma uma peça no domínio exercido pelo poder sobre o corpo. A alma, efeito e instrumento de uma anatomia política; a alma, prisão do corpo (Foucault, 1987, p. 31s).

Isto obriga-nos a voltar ainda uma vez mais ao ponto no qual se buscava polemizar a definição de humano, contra certa concepção humanista; aliás, bastante recorrente. Esta concepção, salvaguardadas as devidas proporções, suas versões e estilos argumentativos, assenta-se na tese geral, porém questionável, de uma suposta dignidade ou sacralidade do ser humano ${ }^{2}$ diante de todos os demais seres vivos e, até mesmo, diante de todo

\footnotetext{
${ }^{2}$ Um exemplo bastante patente dessa tese pode ser encontrada no documento de trabalho intitulado "Reflexão Ética Sobre a Dignidade Humana", de 5 de janeiro de 1999, divulgado pelo Conselho Nacional de Ética para as Ciências da Vida, em Portugal, onde se lê (p. 10): "Em resumo, o termo Dignidade Humana é o reconhecimento de um valor. É um princípio
} 
o meio ambiente. Assim, o que garantiria algum sentido e relevância ética na preservação das variadas espécies de seres vivos e na conservação do meio ambiente como um todo seria a dignidade e superioridade - seja como ser vivo, seja enquanto criatura de alguma divindade, como nas religiões judaico-cristãs e islâmicas - do ser humano. A preservação de qualquer ser vivo e de toda natureza só se justificaria, pois, pela preservação da integridade, da dignidade e da qualidade de vida do humano. Um exemplo, para atermo-nos ao esforço de pensar a partir dos avanços recentes em tecnologia, pode ser encontrado facilmente no artigo "Ética e humanismo em nanotecnologia", de Henrique Toma:

Os avanços no conhecimento exigem que o homem se adapte continuamente a novos preceitos e valores, embora isso não pareça óbvio. O homem já tem o poder bélico para destruir o mundo. Ironicamente, até mesmo sem tocar em armas, já pode levar nações à desgraça pelo exercício dos jogos econômicos. O que acontecerá quando tanto poder for exacerbado? [...] Assim, sob o ponto de vista evolutivo, é importante não dissociar a ciência da consciência humana. Tal descompasso colocará em risco a sobrevivência da humanidade. Essa linha de pensamento não é nova, e tem preocupado muitos cientistas e humanistas desde o início do século passado. Um

moral baseado na finalidade do ser humano e não sua utilização como um meio. Isso quer dizer que a Dignidade Humana estaria baseada na própria natureza da espécie humana a qual inclui, normalmente, manifestações de racionalidade, de liberdade e de finalidade em si, que fazem do ser humano um ente em permanente desenvolvimento na procura da realização de si próprio. Esse projecto de auto-realização exige, da parte de outros, reconhecimento, respeito, liberdade de acção e não instrumentalização da pessoa. Essa auto-realização pessoal, que seria o objecto e a razão da dignidade, só é possível através da solidariedade ontológica com todos os membros da nossa espécie. Tudo o que somos devido a outros que se debruçaram sobre nós e nos transmitiram uma língua, uma cultura, uma série de tradições e princípios. Uma vez que fomos constituídos por esta solidariedade ontológica da raça humana e estamos inevitavelmente mergulhados nela, realizamo-nos a nós próprios através da relação e ajuda ao outro. Não respeitaríamos a dignidade dos outros se não a respeitássemos no outro". O documento pode ser consultado na íntegra no sítio eletrônico do Conselho (http://www.cnecv.gov.pt/CNECV/pt/default.htm).

Filosofia e Educação - ISSN 1984-9605

Volume 6, Número 3 - Outubro de 2014 
reflexo disso foi o surgimento do humanismo, como uma filosofia progressiva de vida que, sem apelar para o supernatural, direciona nossa habilidade e responsabilidade para viver plenamente dentro da ética, almejando sempre o melhor para a humanidade (Toma, 2004, pp. 89-90).

Ora, o sentido de afirmar algo assim consiste em tomar como ponto de partida a defesa prévia do humano dotado, caracterizado por uma essência, sagrada, natural, pouco importa, mas que deve ser tratada como inviolável como um bem em si mesmo que antecede e baliza toda e qualquer conduta no sentido de sua autopromoção, ou que veta qualquer indício de comprometimento da integridade e dignidade dessa essência. Isto é facilmente confirmado pela leitura do Código de Nuremberg - sobre as diretivas para experimentação em seres humanos - em especial a diretiva 6: "O grau de risco a ser assumido não deve jamais exceder aquele determinado pela importância humanitária do problema a ser resolvido pelo experimento". Ou em outros contextos teóricos, porém compartilháveis, o núcleo ético assenta-se na noção de pessoa que, segundo as palavras de Lucien Sève (1994: 86) "na sua acepção ética, a única em que a palavra não é substituível por nenhuma outra, a pessoa é a forma-valor igualmente ascrita a todos os indivíduos, na sua qualidade de pertencentes ao gênero humano". É nessa forma-valor que a humanidade se constitui, eticamente, como dignidade, segundo a fórmula kantiana, presente na Metafísica dos Costumes (apud SÈVE, 1994, p. 156).

Entretanto, antes mesmo de afirmarmos que é o homem, a humanidade, a pessoa, ou o sujeito - todos esses termos que nos valemos, séculos a fio, para dignificarmos e valorarmos o que somos diante de todas as coisas, animadas e inanimadas e, inclusive diante de toda a natureza - o 
valor primeiro e último, o fundamento último de uma ética que deve nos municiar contra os perigos de uma má ciência ou de uma má tecnologia, ou ao menos de seu mau uso, uma pergunta se coloca como fundamental, uma vez que ela é, inevitavelmente capciosa e, geralmente, titubeamos diante de seus caprichos: o que somos nós que nos intitulamos humanos? A esta pergunta, as respostas foram muitas. E todas implicam em vários riscos.

A pergunta pela natureza, ou pela essência, ou pela dignidade, ou pela sacralidade do homem só se faz fundamental, não porque possamos realmente fundar a partir de sua resolução uma ética consistente ou forte. Ela se faz fundamental justamente porque, diante dela, não temos como não titubear e vacilar. A tentativa honesta de respondê-la só pode se dar sob o signo da insuficiência e a da incerteza. Contudo, constatar este limite, talvez nos obrigue a pensar que, num sentido edificante, diante dessa caprichosa pergunta, a resposta deve ser uma outra pergunta: o fundamental não é perguntar pelo que sou, mas o que faço com o que eu sou. Não importa qual seja a minha natureza, se sou determinado mecanicamente, ou se sou organismo - não mais determinado pelas leis físicas que para um filósofo podem ser representadas pelo princípio de causalidade, mas pelas leis teleológicas da preservação do indivíduo ou da espécie, ou seja pela seleção natural - ou ainda, se sou um autômato psicológico, cujo caráter e conduta expressam os reforços (positivos ou negativos) que recebo, ou ainda numa outra vertente psicológica, são como os rastros de minha natureza neurótica. E daí? O que faço, tudo, decorre de determinismos? E se for, e daí? Será que existe apenas um efeito para cada causa? Ou várias causas possíveis para um determinado efeito? Em suma: o que pode sustentar uma exata e estreita relação entre causa e efeito, que determina nossa condição? Portanto, talvez a questão ética fundamental - não por que é a mais básica, elementar ou primeira, mas por que nos faz pensar numa práxis e numa poiésis, isto é, em 
modalidades de agir e de produzir - não resida em como salvaguardo a natureza humana (qual natureza?), mas o que faço, eu que sou humano, de minha e com minha humanidade. Pois como bem nos lembra o poeta português Mário de Sá-Carneiro que, em fevereiro de 1914, escreve:

Eu não sou eu nem sou o outro, Sou qualquer coisa de intermédio: Pilar da ponte de tédio Que vai de mim para o outro.

Portanto, a condição humana "singular" se determina fundamentalmente na interação com um outro, não importa muito que tipo de intermédio (se tedioso ou não como é a opção do poeta), e até mesmo, pois, num ambiente sociocultural. Não há uma determinação subjetiva, egocêntrica, da subjetividade; mas de certo modo, também não há uma determinação alocêntrica, isto é determinada a partir, centrada, no outro. Não é a partir de uma subjetividade, seja a minha própria ou a de um outro, que se põe a questão da determinação de minha subjetividade, seja de um ponto de vista ontológico, antropológico, ético ou mesmo sociopolítico. A ideia central aqui é a determinação a partir da interação, a partir da intermediação, efetiva ou possível. É, portanto, no limite da subjetividade, nos pontos de tangenciamento entre as subjetividades que se deve pôr questões sobre a própria determinação da subjetividade e da possibilidade de se pensar e agir eticamente. E isto é ainda mais patente e emergente diante das provocações advindas dos mais recentes avanços tecnológicos, realizados ou prometidos, previstos ou inesperados.

Contudo, refletir sobre essa questão, não se realiza obrigatória e necessariamente a partir da determinação de um padrão de conduta. Não é o estabelecimento de padrões normativos ou deontológicos que devem marcar tal postura ética. Não que estejamos impedidos de pensar no sujeito, ou no

Filosofia e Educação - ISSN 1984-9605

Volume 6, Número 3-Outubro de 2014 
homem, ou na pessoa, na sua dignidade; ou mesmo impedidos de pensar em normas. Mas até que ponto resolvemos efetivamente as coisas com definições éticas sobre o que é bem e mal, justiça e injustiça, dever e liberdade? E até mesmo em que medida resolvemos eticamente os impasses tecnocientíficos com uma definição, qualquer definição, prévia do que é ser humano e sua respectiva dignidade? Muitas vezes, somos pegos de surpresa e desafiados pelas novidades tecnológicas que chegam numa rapidez estupenda: sequenciamento do genoma humano, ovelha Dolly, transgênicos, terapias com células tronco, clonagem de embriões, tecido sintético, drug delivery, máquinas biomecânicas, próteses nanotecnológicas... Será que, realmente, definições prévias podem dar conta desses desafios?

Essa presunção ontológica e a-histórica do humanismo, geralmente vem acompanhada de uma presunção a definir padrões e condutas morais a partir de preceitos legislativos ou normativos, cuja única diferença é se o móvel é externo (as leis de um país, p. ex.) ou interno, ou seja, determinados pela autonomia da razão, ante as desventuras fáticas por que passamos todos nós. Não há, grosso modo, como não ver nisso a influência de certo aufklärer: Imanuel Kant. A tese kantiana de se conceituar a liberdade como o respeito a uma máxima que, por sua pretensão de universalidade, se faz lei: "age de tal sorte que a máxima da tua vontade possa ao mesmo tempo sempre valer como princípio de uma legislação universal" (sigo a transcrição de Angèle Kremer-Marietti, 1989). Ou como Kant mesmo afirma: “A liberdade do arbítrio é a independência de sua determinação por impulsos sensíveis; este é o conceito negativo da mesma. O positivo é: a faculdade da razão pura de ser por si mesma prática. Especificamente aí, isto só é possível submetendo a máxima de cada ação às condições de aptidão para converter-se em lei universal" (Kant, 1994, p. 213). 
Como alternativa à tese kantiana da liberdade enquanto autonomia, isto é, a capacidade racional de prescrever para si mesma leis que devem ser configuradas como válidas não para um indivíduo, mas para todos, isto é, universalmente, gostaríamos de propor uma concepção de liberdade caracterizada como autocracia. Esta outra concepção não contradiz nem invalida aquela, apenas focaliza outro aspecto já presente ali ainda que de modo pouco explorado: em vez de se focar na máxima de cada ação, lançase sobre o próprio ato criador de criar máximas morais (ou não) e de correlacioná-las com ações. É a liberdade, não de se guiar por normas de pretensão universal, mas a liberdade de poder criar para si mesmo regras de conduta. Acreditamos que podemos buscar suas pistas num outro filósofo: Michel Foucault.

Foucault não nos apresenta de forma tão sistemática - o que, de qualquer modo, não é motivo de constrangimento teórico, uma vez que se trata de um pensador prolífico em idéias instigantes, contudo pouco dado a maiores sistematizações teóricas - uma concepção sua de ética. Todavia, estudos recentes têm se mostrado bastante contundentes no sentido de verificar no filósofo um esforço de abordagem ética. Ela reside principalmente a partir de seus trabalhos em torno dos dois últimos volumes de sua História da Sexualidade, publicados em 1984 e, provavelmente, ela apresenta alguma de suas principais marcas no curso conhecido como $A$ Hermenêutica do Sujeito, ministrado no Collège de France em 1981/1982.

Buscaremos formular, a partir desse momento um esboço mínimo de sua concepção ética para, em seguida, retomar o pano de fundo dos desafios nanotecnológicos, intentando uma aplicação (forçada talvez, porém instrumentalizada e não necessariamente correta em sua hermenêutica) da ética foucaultiana. 
O fundamental, tanto para compreendermos minimamente o filósofo francês, bem como para podermos instrumentalizá-lo teoricamente, consiste em notar que, a despeito das primeiras aparências, Foucault (1994, p. 383) fala de seu real interesse: "[...] estou muito interessado nos problemas sobre as técnicas de si e coisas deste tipo". Ou seja, seu objetivo mais radical consistia em inventariar e analisar genealogicamente as maneiras pelas quais as pessoas se voltam sobre si mesmas num sentido de se cuidarem. A questão não é exclusivamente a máxima socrática "conhece-te a ti mesmo" (gnôthi seauthón), mas a sua inserção num contexto mais amplo que é o do cuidado, o cuidado pela vida, pela própria vida e, assim, por decorrência, o cuidado de si - o que os gregos chamavam de epiméleia heautôิ, e os latinos cura sui. É esse o tema geral de seu curso no ano letivo 1981/1982, A Hermenêutica do Sujeito (Foucault, 2004, pp. 4 e 597) - texto chave para entendermos, senão conclusivamente, ao menos significativamente suas reflexões éticas.

E à noção de "cuidado", Foucault relaciona com a de "técnica". Especificamente com a noção grega da technè tou biou (1994: 390), a arte, ${ }^{3}$ a técnica da vida, do viver; a técnica pela qual gerimos e configuramos nossas vidas, fazendo delas obras de arte - daí que, neste sentido, nosso poder de configurar nossas vidas, pode ser interpretada mediante a fórmula da estética da existência. Mas é uma arte que seu exercício deve ser moldado, treinado (Foucault, 1994, p. 404): "nenhuma técnica, nenhum talento profissional pode ser adquirido sem prática; e não se pode aprender a arte de viver, a technè tou biou, sem uma askêsis que deve ser considerada como uma aprendizagem de si por si."

\footnotetext{
${ }^{3}$ É importante não esquecermos que a noção de "arte" tem mais o sentido de artesanato, ofício artesanal, quase uma bricolagem, que qualquer parentesco com as belas artes. Por isso Foucault trabalha indistintamente com as noções de "arte" e "técnica", a despeito mesmo de sua expressão um tanto vaga de "estética da existência", que muitas vezes fica subordinada à noção de "hermenêutica do sujeito".
}

Filosofia e Educação - ISSN 1984-9605

Volume 6, Número 3 - Outubro de 2014 
Obviamente, não devemos apressadamente esperar das reflexões foucaultianas alguma espécie de analogia com as reflexões da teoria crítica (especialmente Horkheimer e Adorno com sua Dialética do Iluminismo) ou a heideggeriana acerca da técnica. Sobre este último, Foucault observa em seu caderno de anotações (de 1980), para uma conferência em Berkeley, que "Para Heidegger, é a partir da technè ocidental que o conhecimento do objeto selou o esquecimento do Ser. Retornemos à questão e perguntemonos a partir de quais technai se formou o sujeito ocidental e foram abertos os jogos de verdade e erro, de liberdade e coerção" (apud Gros, in Foucault, 2004, p. 634s).

Ou seja, a despeito das diferenças entre os gregos e os latinos em relação à nossa modernidade, é possível perceber no jogo genealógico da contraposição, na existência de éticas modalizadas por técnicas variadas que não só regulamentam, mas que primordialmente realizam, ou permitem realizar, multifacetadas maneiras de constituição dos indivíduos como sujeitos, e como sujeitos éticos - não em termos ontológicos e a-históricos, mas fundamentalmente em termos históricos, onde nós, como indivíduos e sujeitos, podemos constituir-nos nossas identidades e diferenciações. Introduzimos assim a noção de "diferença" que se faz pertinente para pensarmos uma projeção ética de nossas vidas - no presente caso, amparado pelas reflexões foucaultianas. E, desse modo, não há como se furtar em estabelecer um equacionamento teórico entre relações de poder e conduta ética.

E como essa atualização ética de nossa singularidade pode se realizar a partir dos desafios que as novas tecnologias nos afrontam quase que diariamente? Pelo menos um aspecto precisa ser considerado como um dos traços distintivos das implicações das novas tecnologias, em nossa singularização ética. Sob o signo das novas tecnologias e de seus feitos, as

Filosofia e Educação - ISSN 1984-9605

Volume 6, Número 3 - Outubro de 2014 
mediações virtuais (e, pois realizáveis) que se estabelecem entre os indivíduos singulares, e entre os indivíduos e a sociedade em geral, são mediações indiretas, mediadas pelos feitos tecnológicos. A interação ética que travo comigo mesmo e com o outro passa necessariamente, no caso específico das novas tecnologias, pela mediação dos artefatos por elas projetados e produzidos. Não há propriamente nenhuma novidade nisso, posto que a interação ética mediada por artefatos é algo relativamente comum a partir das tecnologias mais recentes, com as quais temos convivido pelo menos desde as primeiras décadas do século XX.

Essas mediações são as mais variadas e não cabe aqui inventariarmos suas tipologias. Basta para nós atentarmos ao fato de que simbolicamente naturalizamos os artefatos, tornando-os fatos - e como tais, deixam de ser objeto de discussão e disputa, e passam a ser o próprio fiel da balança numa disputa qualquer, conferindo ao vencedor o direito de verdade e justiça. Bruno Latour $(1999,2003)$ tem trabalhado bastante este aspecto. Principalmente nas disputas intelectuais travadas no momento mesmo do estado de arte das ciências e engenharias quando a natureza é 'acionada' como parceira definitiva e aporte de objetividade de um dos lados da contenda. Porém, mais interessante do que percebermos que podemos reclamar para nós que a natureza jogue a nosso favor, é perceber que para que isso ocorra, a natureza não é uma realidade dada de antemão, e muito menos os objetos que científica e tecnologicamente apreendemos (seja a partir de sua concepção e construção, seja a partir de sua manipulação para atingir outros fins). A natureza e "seus" objetos são, sob certo sentido, artefatos, construtos. Há uma concepção ontológica de realidade, das coisas, e de nossa inserção humana pressuposta aqui. Assim como não somos dotados de uma natureza, de uma essência, de uma condição fundamental, as coisas em geral e a natureza como um todo também não. $\mathrm{O}$ que, 
certamente, deixa a grande maioria da comunidade científica desconcertada. Afinal, o objeto de seu conhecimento científico não é algo dado, passível de ser descoberto; mas algo a ser construído, concomitantemente à construção de seu conhecimento sobre tal coisa - a descoberta científica se dá na construção tecnocientífica do fato (mas isto é uma outra reflexão que as nanotecnologias nos suscitam e que não cabem neste momento).

Outro aspecto a ser considerado: enquanto mediador os artefatos tecnológicos "funcionam" como uma espécie de extensão da ação humana. Basta lembrarmos da situação extremada da destruição de Hiroshima e Nagasaki pelas bombas atômicas Little Boy e Fat Man, respectivamente; principalmente pelo fato de que o homem sabia dos efeitos nefastos das armas atômicas e rapidamente devastadores por ocasião do lançamento de Fat Man. Claro que não precisamos sempre pensar em situações-limites de extrema periculosidade e que implicam na óbvia ameaça de nossa integridade humana. Tampouco em transformar toda a reflexão ética num cálculo entre riscos e vantagens, na qual, muitas vezes, os riscos são supervalorizados; e caminhamos em direção a uma perspectiva fatalista de nossas vidas, nos momentos presente e futuro. É necessário, para governarmos a nós mesmos conferir aos riscos sua real dimensão e lugar. Para isso, como observa Dupuy (2004, p. 60),

É preciso compreender que 1) os riscos nada mais são que um tipo de efeitos dentre muitos outros, e certamente nem os mais importantes nem os mais interessantes; 2) o cálculo dos riscos, que é o único método de avaliação considerado, é completamente impróprio para a apreensão normativa da maior parte dos efeitos.

Filosofia e Educação - ISSN 1984-9605

Volume 6, Número 3 - Outubro de 2014 
Mas é também fundamental perceber que os efeitos, preconizados e imprevistos, a despeito de sua natureza benéfica ou deletéria, pertencem à condição mesma dos artefatos. Por isso, os artefatos tecnológicos em geral e os nanotecnológicos, os biotecnológicos, os genéticos e os informacionais em particular, como epígonos dos novos avanços tecnológicos - são mediadores das ações humanas e, nesse sentido, o conhecimento desses efeitos, bem como seu controle, é parte integrante do governo de si e do governo dos outros.

Assim, por exemplo, os efeitos nanotecnológicos (mas perfeitamente aplicável a todas as novas tecnologias) têm, para além de sua evidente faceta tecnológica; ou melhor: imanente à sua faceta tecnológica, os nanoartefatos também têm sua faceta ética e política. Projetar, conceber, fabricar nanoartefatos é agir social e coletivamente. Portanto, é agir com os outros, sobre os outros e consigo mesmo. E a liberdade de ação, mediada pelos nanoartefatos, é o exercício autocrático, de poder sobre os outros, com os outros e sobre si mesmo. E como se trata de uma condição simultaneamente individual e coletiva, porquanto eminentemente social, é uma ação mediada não apenas pela concepção e fabricação em sentido estrito dos artefatos em escala nanométrica, mas que também depende da recepção e re-ação do coletivo afetado por esses mediadores nanotecnológicos. Assim, cientistas e nanotecnólogos devem levar em conta também as reações, favoráveis ou não, da sociedade em geral, personificada ou representada por um coletivo específico (como a comunidade dos cientistas a que pertencem) ou mais ampla, como por exemplo a interlocução com outros especialistas de outras áreas (filósofos, cientistas sociais, jornalistas, dentre outros), e com a sociedade civil como um todo, representada por ONG's (Greenpeace, ETC Group, e outros) e demais organismos pró-cidadania. Enfim, várias são as possibilidades de ações e inter-relações autocráticas, isto é livres e éticas, 
consideradas relevantemente cada situação de mediação nanotecnológica. O importante é que não se perca a condição pública e coletiva da ação livre, especialmente os cientistas e nanotecnólogos, sem decair em presunções epistemocráticas - isto é, que seu conhecimento sobre o nanomundo os proteja ou os libere de quaisquer questionamentos da sociedade, da qual eles pertencem, e de que estejam liberados de esclarecer e informar a sociedade como um todo. Portanto, que se busquem sempre ações livres, democráticas, públicas; que as novas tecnologias, enquanto formas de viver e de agir, sejam sempre exercícios de liberdade.

\section{Referencias bibliográficas}

BENJAMIN, Walter. A obra de arte na era de sua reprodutibilidade técnica. In: Obras Escolhidas. Vol. I: magia e técnica, arte e política. São Paulo: Brasiliense, 1985. p. 165-196.

CONSELHO NACIONAL DE ÉTICA PARA AS CIÊNCIAS DA VIDA. Reflexão ética Sobre a dignidade bumana. Portugal: CNECV, 1999.

DUPUY, Jean-Pierre. Le problème théologique-scientifique et la responsabilité de la science. 2004. (localizado no sítio eletrônico http://formessymboliques.org/article.php3?id article $=66 \#$ nb17).

FORTY, Adrian. Design industrial e prótese. In: AFONSO, Rui Braz \& FURTADO, Gonçalo (coord.). Arquitectura - máquina e corpo: Notas sobre as novas tecnologias na arquitectura. Porto (Portugal): FAUP, 2006. p. 19-31.

FOUCAULT, Michel. A Hermenêutica do Sujeito. São Paulo: Martins Fontes, 2004.

FOUCAULT, Michel. À propos de la généalogie de l'éthique: um aperçu du travail en cours. Dits et Écrits. Tome IV. Paris: Gallimard, 1994, p. 383-411.

FOUCAULT, Michel. Vigiar e Punir. Petrópolis: Vozes, 1987.

KANT, Imanuel. La Metafísica de las Costumbres. Madrid: Tecnos, 1994. 
KREMER-MARIETTI, Angèle. A Ética. Campinas: Papirus, 1989.

LATOUR, B., Ciência em Ação. São Paulo: Editora Unesp, 1999.

LATOUR, Bruno. Pasteur et Pouchet: Hétérogenèse de l'Histoire des Sciences. In: SERRES, Michel (org.). Éléments d'Histoire des Sciences. Paris: Bordas, 2003.

SÈVE, Lucien. Para uma Crítica da Razão Bioética. Lisboa: Instituto Piaget, 1994.

SLOTERDIJK, Peter. Regras para o Parque Humano: uma resposta à carta de Heidegger sobre o bumanismo. São Paulo: Estação Liberdade, 2000.

TOMA, Henrique. Ética e humanismo em nanotecnologia. Parecerias Estratégicas. Brasília, v. 18, p. 87-96, 2004. 